\title{
東海豪雨による新川破堤汇濫の数値解析 NUMERICAL ANALYSIS \\ ON INUNDATION DUE TO THE SHIN RIVER BREACH CAUSED BY TOKAI HEAVY RAIN
}

\author{
清宮 洋1 ・片田 敏孝 2 ・真野 明 3 \\ Hiroshi KIYOMIYA and Toshitaka KATADA and Akira MANO

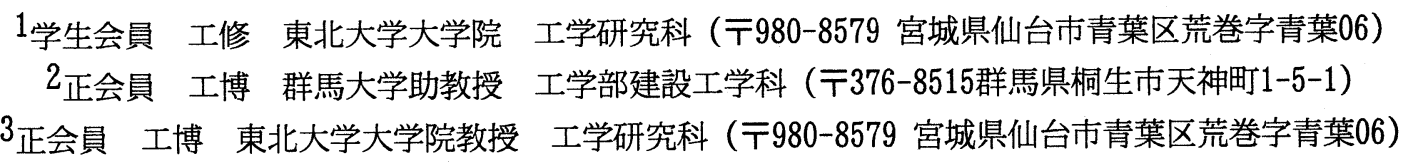

The mathematical model which can simulate inundation process in the urban areas due to heavy rain has been developed. The problems of model are to devise the configuration of the grid and to consider buildings, sewage system, streams etc. In this study, the numerical simulation was conducted to reconstruct the Shin-river breach caused by Tokai heavy rain in September 2000. This model employed the ground elevation as the initial condition and the overflow discharge at breach point as the boundary condition. Governing equations are 2-D continuity and momentum equations to simulate urban overland inundation. The result of the numerical simulation was represented by GIS and compared with the field data obtained by the questionnaire. These results indicate the accuracy of this inundation simulation and are helpful in flood management in the future.

Key Words : inundation simulation, , actual measurement, numerical condi tion

1. はじめに

2000年9月11，12日に愛知県を中心とした東海地方を 台風14号と秋雨前線の影響による集中豪雨が襲った.こ の豪雨は総雨量にして $567 \mathrm{~mm}$ ，時間雨量にしても93m いう記録的なものであり死傷10名を出し, 被害総額は愛 知県で8500億円にのぼる大惨事となった.この雨の影響 により名古屋市を流れる一級河川である新川では，本流 である庄内川から最高で $270 \mathrm{~m}^{3} / \mathrm{s}$ の分派を受けたことに より長時間，長区間において計画高水位を上回りいつど こで破堤してもおかしくないような状況下にあった.そ のような中で，9月12日3時30分に名古屋市西区あし原に おいて新川の左岸か破堤したし,これにより西区はもち ろん下流に位置する西枇杷島町の全域においても浸水被 害が生じた.

さて,近年，河川汇濫ハザードマップを作成し，それ を事前に住民に周知させて防災に役立てることが盛んに 行われている.ハザードマップを作成するためには通常， 2次元不定流方程式を用いて数值解析を行うが, 河川か らの流入条件，境界条件，抵抗係数などさまざまな条件 を決める必要がある.これらは主に実験的検証から研究 が進められているが，破堤から汇濫する過程を再現する というような実際のハザードマップ作りに必要な全体的
な数值シミュレーションを行った場合に，どの程度その 解の精度が保証されるのかは定かでない。

そこで本研究は, 前述した新川の破堤汇濫による浸水 被害を数值解析によって再現し, それを実測データと比 較することによる汇濫シミュレーションの精度の検証を 目的とする.今回用いた実測デー夕は, 被災後に実施さ れた住民からのアンケート調査から得たものであり,こ の調査では回答者の居住地に加えて, 床下浸水や床上浸 水の開始封刻, 最高浸水時の浸水深や発生時刻など, 浸 水過程の各段階における汇濫水の状況について質問して おり, 各地域における最大浸水深のみならず, 汇濫の浸 水過程など, 刻一刻と変化する汇濫流の挙動を把握する ことができた.また，これまで新川の破堤汇濫について は, 辻本, 松尾, 武田らにより地盤デ一夕(標高)を初期 条件とする平面2次元不定流モデルから再現, 検証され てきたが邦際に各地区で発生した浸水深の定量的変化 については十分に検討がなされていない.そこで本研究 では，アンケート結果の実測データを補間することによ り浸水深の定量的な時系列変化を表し，これを数值シ ミュレーション結果と比較した.ここでは,GISを用いた 破堤後12時間までの平面的な比較に加え, 領域内から任 意に選んだ地区における浸水深の定量的な比較を試みた。 


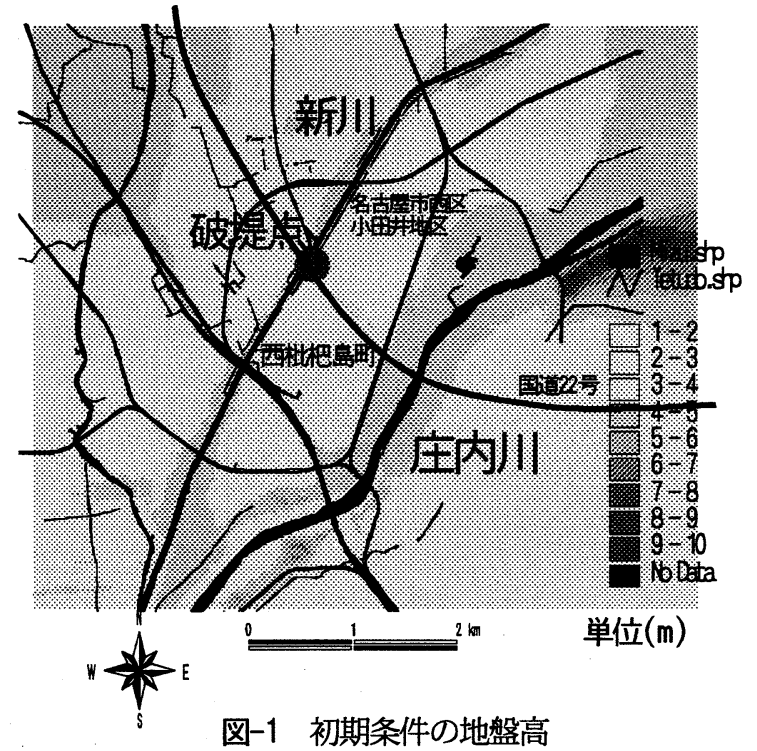

計算では，破堤時刻を0時とし，12時間前からの降雨を 考慮することにより開始時刻をー12時とした。

\section{2. 数值解析のモデル}

\section{（1） 浅水流方程式}

数值解析には，以下に示す浅水流方程式を基礎式とす る.これらの式は, $x, y$ を平面の 2 次元座標とし, 鉛直 方向に連続式と運動量方程式を積分し，圧力分布に静水 圧近似を用いることにより得られる21.式(1)が連続式で あり，式(2)および式(3)が運動量方程式である.

$$
\begin{gathered}
\frac{\partial \zeta}{\partial t}+\frac{\partial M}{\partial x}+\frac{\partial N}{\partial y}=r_{e} \\
\frac{\partial M}{\partial t}+\frac{\partial}{\partial x} \frac{M^{2}}{D}+\frac{\partial}{\partial y} \frac{M N}{D}=-g D \frac{\partial \zeta}{\partial x}-\frac{1}{\rho} \tau_{x} \\
\frac{\partial N}{\partial t}+\frac{\partial}{\partial x} \frac{M N}{D}+\frac{\partial}{\partial y} \frac{N^{2}}{D}=-g D \frac{\partial \zeta}{\partial y}-\frac{1}{\rho} \tau_{,} \\
\tau_{x}=\frac{\rho g n^{2} U \sqrt{U^{2}+V^{2}}}{\zeta^{1 / 3}} \tau_{y}=\frac{\rho g n^{2} V \sqrt{U^{2}+V^{2}}}{\zeta^{1 / 3}}
\end{gathered}
$$

式中において， $\zeta$ : 基準面から上方にとった水面変 位, $D=h+\xi$ : 水面から水底まで鉛直方向に計った全 水深, $h$ : 基準面から水底までにとった静水深, $M=U D, N=V D: x, y$ 方向の単位幅流量, $U, V:$ $x, y$ 方向の断面平均流速, $\tau$ : 水底に働くせん断応力 で， $x, y$ の下の添え字はそれぞれの方向の成分， $\rho$ : 密度, $g$ :重力加速度, $\boldsymbol{n}$ : 汇濫原粗度係数である.また, $r_{e}=\max (r-d c, 0)$ であり, $r$ : 降雨強度, $d c:$ 下水 道の排水能力 $(50 \mathrm{~mm} / \mathrm{hr}$ )である.

右辺の第1項が圧力項で, 重力の効果により水面の高い 所から低い所に向けて力が働き, 波が伝播する. また, 右辺

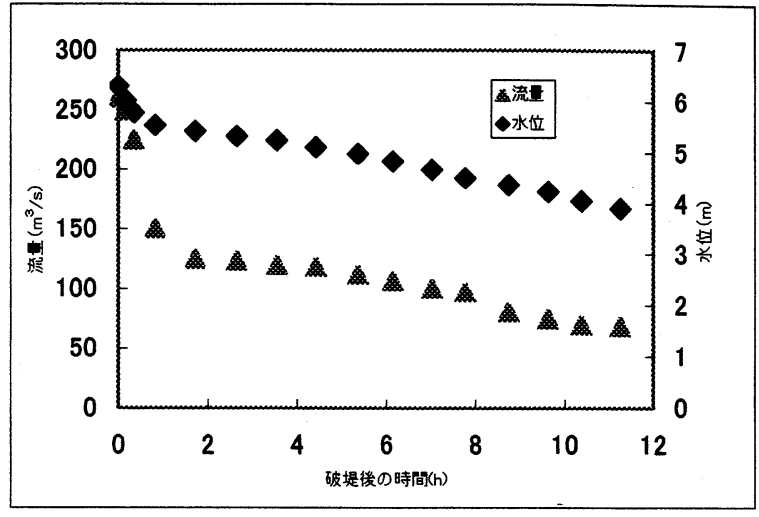

図-2 破堤部における氾濫流量

の第2項は水底に㗢せん断応力, 寸なわち摩擦応力の項 である. 定常流，あるいは波高との相対量として浅いところ の現象を扱うときには無視できない量となる.

\section{（2）本間の越流公式 ${ }^{3 !}$}

数值計算における境界条件としての破堤点での汇濫流量 は, 以下に示す本間の越流公式が一般的に用いられる. 本 間は台形せきに関する実験から $h_{2} / h_{1}\left(h_{1}, h_{2}\right.$ : 破堤部に おいて敷高から見て高い方の水位と低い方の水位)の大 きさによって完全越流 $\left(h_{2} / h_{1} \leq 0.45\right)$, 不完全越流 $\left(0.45 \leq h_{2} / h_{1} \leq 0.8\right)$, もぐり越流 $\left(0.8 \leq h_{2} / h_{1}\right)$ の3種類の越流状 態に分類されることを明らかにし，それぞれの流況について 流量式を与えている. 今回の計算では, もぐり越流の公式を 用いた. ここで, $Q_{0}$ は氾濫流量, $B$ は破堤幅である.

$$
Q_{0}=0.91 B h_{2} \sqrt{2 g\left(h_{1}-h_{2}\right)}
$$

\section{3. 計算条件}

\section{（1）初期条件}

初期条件には地盤高を設定した. 地盤高には数值地図 50mメッシュ(標高) $)^{4)}$ 用いたが，現地実測および下水道 台帳図面から得た標高データと比べ西区小田井地区の新 川沿いにおいて高すぎる䇢所があったため,1mから $1.5 \mathrm{~m}$ の補正を行った. 図-1にその分布を示す.また,新川堤防, 国道22号および銑道の線路においては比高が2程度の盛 土とした.水路および下水道を考慮に入れた内水汇濫解 析は本研究では行っていない.

\section{（2）境界条件}

境界条件には破堤部における汇濫流量をあてはめる. 汇濫流量を求めるには2-(2)で述べた本間の越流公式を 用いるが，そこに代入する破堤部における河川の水深と その時の汇濫流量の時間変化を図-2に示す. 


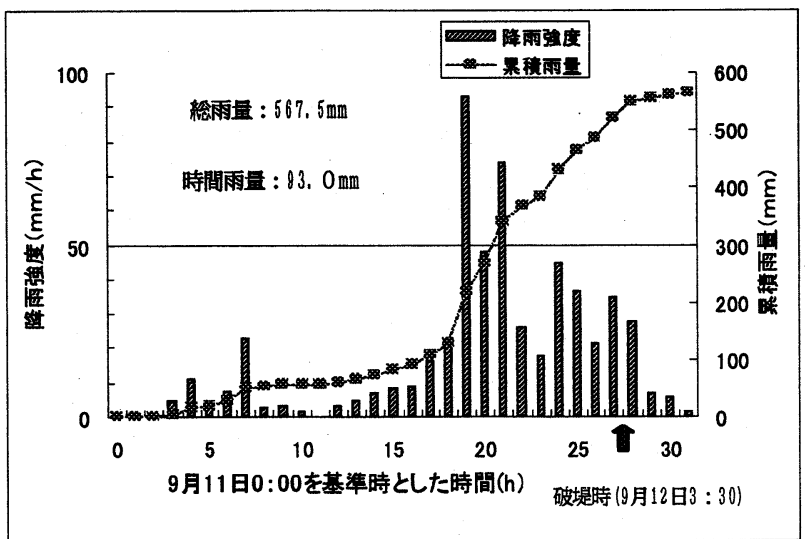

図-3 9月11日0：00から12日7：00における名古屋雨量観測 所での1時間おきの降雨強度と累積雨量

\section{(3) 粗度係数}

計算領域は主に住宅地であるために建物による摩察の 影響を考慮しなくてはならない. 汇濫原粗度係数につい てはさまざまな粗度係数が提案されており（例えば Xanthopoulousら ${ }^{5)} ， 1976 ） ， そ の$ 他にも建物占有率に 応じて粗度係数を決定する方法なども提案されているが (栗城ら $\left.{ }^{6)}, 1996\right)$ ，今回は汇濫域を一様に市街地とみな して, Xanthopoulousら（1976）にならうことにして $n=0.067$ とした"

\section{（4）雨水排除システムの考慮}

降雨は，破堤以前にピークをむかえた. 気象庁の名古 屋雨量観測所によると，9月11，12日において，総雨量 $567.5 \mathrm{~mm}, 60$ 分最大雨量 $93 \mathrm{~mm}$ という未曾有の降雨であっ たことがわかる. 計算ではこの雨を 1 時間毎の降雨強度 8)であらわして（図-3）計算領域全体に一定の降雨を与 えた.ここでポンブ排水施設や下水道施設の影響につい てだが，本研究ではこれらの運転状況を取り込む解析シ ステムが十分に構築できていないことから次のようなモ デルを考えた. 名古屋市では総合排水計画にもとづき, 時間雨量 $50 \mathrm{~mm}$ に対応する治水施設整備を平成 12 年の完成 を目標として進められてきた.そこで，この東海豪雨時 に，対象域において，時間雨量50m的対応する排水施設 が一様に整備されていると仮定し，計算上，各格子に溜 められた汇濫水に対して，時間雨量50m的に相当するボ リューム分を瞬時に差し引くという簡便なモデルを考え 適用した.この方法を用いると，図-3に示した時間雨量 $50 \mathrm{~mm}$ のライン上回る降雨では, 完全排水されず, 浸水 が発生することになる.

\section{4. 数值解析の結果}

\section{（1）GISによる浸水深の表現}

数值解析を行った結果をGISを用いて平面的なグラフ にした(図-4). グラフは, 50mメッシュで読み込んだ120
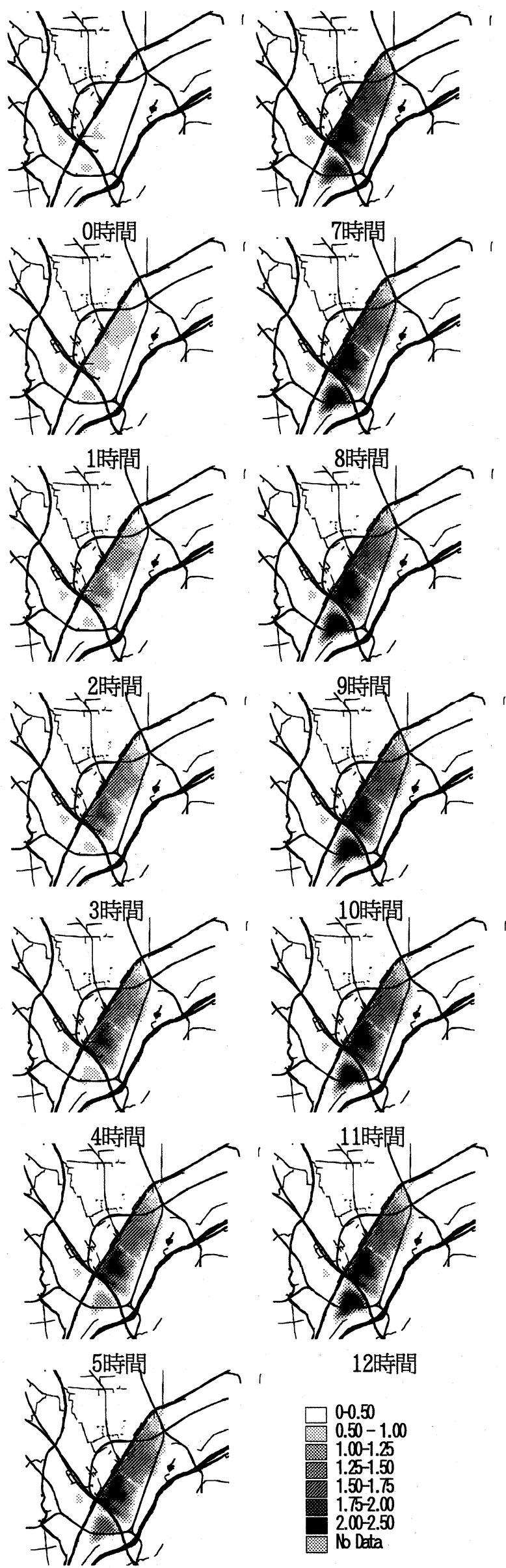

6時間

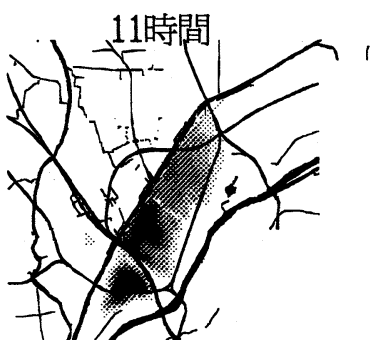

12時間

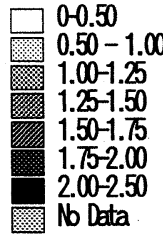

単位(m)

図-4 数值解析の結果の時系列変化 
行90列のデー夕を補間して得たもので,0.25m毎の濃度を 変化させることによって浸水エリアにおける浸水深を表 した. 破堤以前に降った雨による浸水図を始めとして, その後，破堤から 1 時間おきの浸水図を12時間目まで示 す.

\section{（2）浸水の様子}

まず，破堤前の降雨による浸水だが，浸水している箇 所は，図-3の地盤高の低い箇所と重なっている. その後， 破堤してから一気に汇濫流が流れ込んだ様子がうかがえ る. 汇濫流も地盤高の低い方へと時間を追うごとに流れ 込んでいく. 北部においては, 時間ごとの浸水深の広が りがよく表れていて，地盤の低いエリアに徐々に流れ込 んでいき破堤後5時間で1.5mほど溜まってから，さらに 北部一帯の名古屋市西に広がっていっている. また，中 部においては，全体的区に地盤が低いこともあり，破堤 後1時間で1.5mほど浸水した個所もある. その後, 破堤 部より少し下流に位置する新川沿いのエリアにおいて時 間ごとに急速な浸水の拡大が表れている.

浸水エリアの広がりは，破堤後6時間あたりまでで庄 内川までは氾濫流は達してはいないが, 浸水深において は，破堤後4時間で，すでに2mをこえる浸水も生じてい て，その後も流入は続き12時間後には2.5mにも達した 箇所がある. また，国道22号線においては始めの 1 時間 目では，浸水を妨げている様子がうかがえるが，その後 架橋下の通路を通って浸水が広がっていくように計算で は考慮されている.これと同様に南部での浸水において は, 西枇杷島町を横切る東海道本線によって，はじめの 3時間目あたりまでは浸水が妨げられている. その後, 徐々に架橋下の通路から進出していく様子がうかがえる. これによって, 南部の地盤高が低いエリアにおいても大 きな浸水が生じていて，12時間後には，2.5m近く浸水が 生じている.

\section{5. 実測值の集計}

\section{（1） 実測データ}

汇濫の実測值としては, 群馬大学の片田研究室によっ て集められた被災後の住民からのアンケート結果を集計 したものを用いている.このアンケートは，汇濫域にお ける各建物の, 床上, 床下浸水時, 避難時, 最大浸水時 の4点の時間と浸水深を可能な限り回収したものであり， このデータを補間することによって町ごとに分割したエ リアにおける時系列の浸水深の変化を表し, 計算值と同 様にGISで表した。

\section{（2）浸水の様子}

図-5に示す浸水の様子を見ていくと，はじめのうちは， 破堤点のあし原町から新川沿いにおいて広がっていって
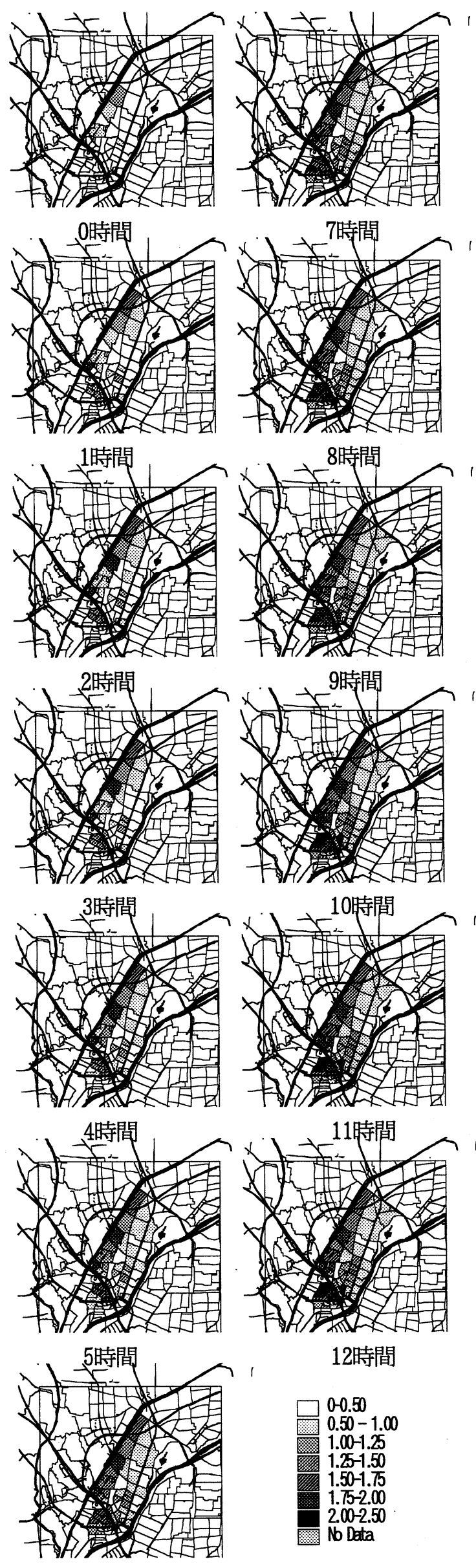

12時間

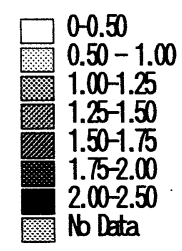

6 時間

単位(m)

図-5 浸水深実測值の時系列変化 


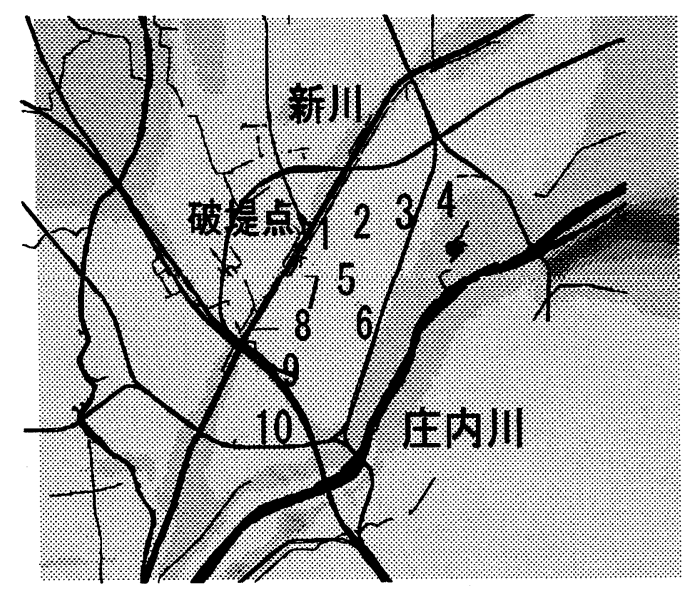

1. あし原 2. 中小田井 3 丁目 3.中小田井2丁目

4. 上小田井 1 丁目 5 .古城 2 丁目 6 .城並 1 丁目

7. こも原 8. 地領 1 丁目 9. 壱反五敏割 10. 芝野新田

図-6 浸水深の定量的比較箇所

いる. 特に上流部の中小田井町では, 破堤以前の降雨に よる浸水の段階からすでに1m前後の浸水があり，破堤か ら 1 時間で急激に深くなっている. また，東海道本線の 南側の特に地盤高が低い個所においても破堤してすぐに 1m以上の浸水が生じている. その後, 徐々に内地へ浸水 が広がっていく様子が見られる.浸水深においては， データの補間により時間の経過で比例的に大きくなるよ うにしているために，それぞれの町では最大浸水深に達 する時間までは単調増加している，最終的には，新川沿 いのほぼ全域と南部において2前後の浸水が生じていて， 最大浸水個所は破堤部に近い地領町(図-6参照)で2.4mと なった.

\section{6. 浸水深の定量的比較}

4,5によって計算值と実測值それぞれにおける浸水の 様子を平面的に表すことができた.この章では，平面的 な結果に加え，計算領域内の任意の10点(図-6)において 1時間おきの計算值と数点の実測值を定量的にとらえた グラフ(図-7)をまじえて, シミュレーションの精度を検 証する。

図-7のそれぞれのグラフを見ると，全体的に計算值と 実測值は非常によく一致している.生じた誤差も大部分 は数 $10 \mathrm{~cm}$ 以内でありシミュレーションの精度はとても良 いといえる. 本研究では排水不全による内水汇濫は考慮 されていないが, 地盤高と汇濫原粗度係数を用いること により破堤による汇濫流の挙動は良く再現できたといえ る.一方で, 2. 中小田井3丁目, 3. 中小田井2丁目のよ うに計算值と実測值にずれが生じている箇所もあり，よ り精度を高めるには内水汇濫の考慮が必要となってくる.

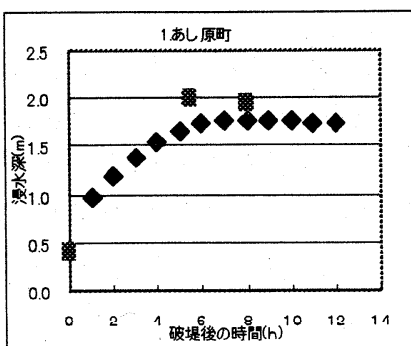

1.あし原町

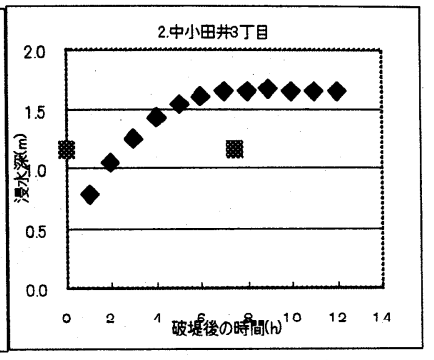

2.中小田井3丁目

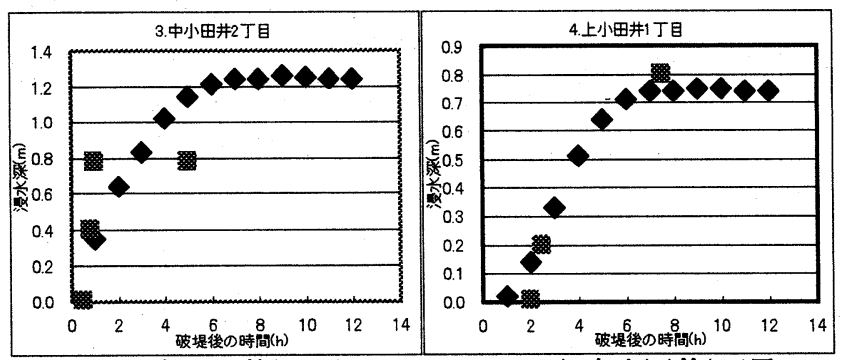

3.中小田井2丁目

4.上小田井1丁目
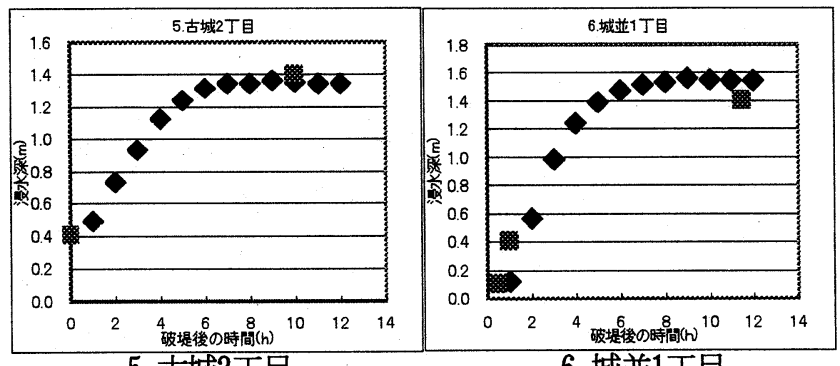

5.古城2丁目

6 .城並1丁目
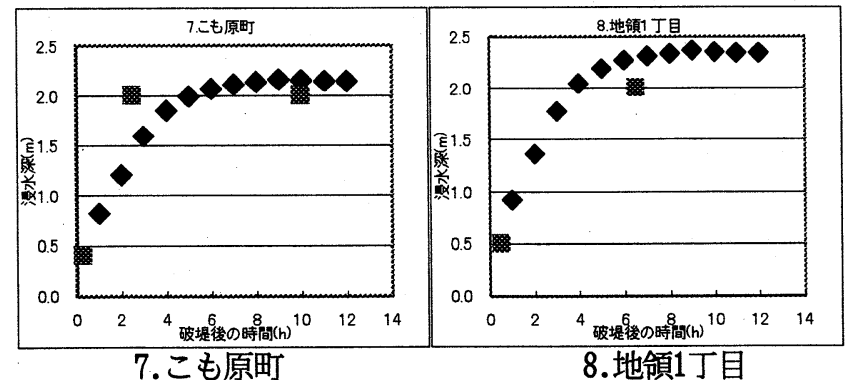

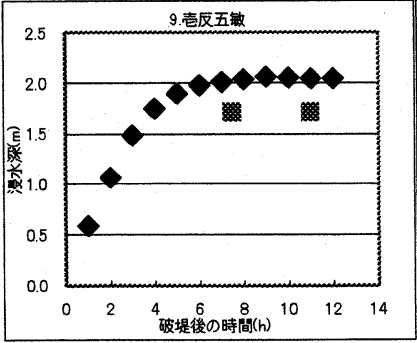

9.壱反五敏割

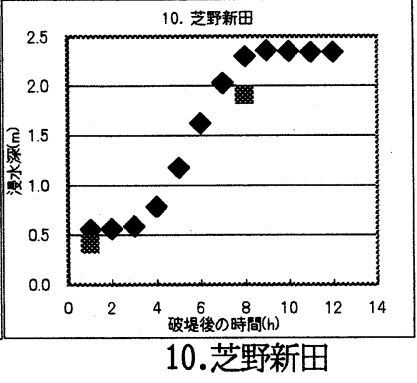

: 実測値
: 計算値

: 实徂

図-7 浸水深の定量的比較 
その他に,誤差の原因として考えられることは,実測値である アンケート結果の集計方法である.アンケートは,汇濫域 内の町ごとに集められており,1つの町内で複数の回答が 得られた場合は,最もよく回答されているデー夕を用い ている.しかし,町内でも浸水深に違いがあると思われ， また, 回答家屋の正確な位置もわかっていない.その他, 家屋の床下は $30 \mathrm{~cm}$ とし,浸水対策として土台が高くされ ている場合は50cmとして考えたが, 害際は各家屋ごとの 高さは一定ではない.アンケート結果自体も,浸水時に自 宅にいたかどうかにより回答精度は変わると思われるこ とや,被災後に住民から集められたデータであるため,浸 水時間,浸水深は正確な值とはいえない。

\section{7. 結論}

・GIS を用いて計算値および実測值を平面的にとらえ， 比較することができた。

・地盤高をもとに，破堤による汇濫流および粗度係数， 降雨, 下水道システムの影響を考慮にいれた数值解 析を行い実測值と比較した結果, 全体的には非常に 精度の高いシミュレーションであることがわかった。

・局所的にみると，誤差が大きくなる箇所もあり，原因 の細かい解明と, より正確な解析システムの構筑が今 後の課題である.

\section{参考文献}

1）辻本哲郎:2000 年 9 月東海豪雨災害に関する調査研究, pp.91-105, 2001

2）池田駿介: 流体の非線形現象一数理解析とその応用一, pp.57-58, pp103105, 1992

3）土木学会:水理公式集, pp.287-288, 1985

4）国土地理院:数值地図 50m メッシュ(標高)一日本 II,1997.

5) Xanthopoulous, Koutitas : Numerical Simulation of a Two Dimensional Flood Wave Propagation Due to Dam Failure ,Jour.Hydraulic Research,Vol.14,No.2,pp.321330,1976.

6）栗城稔，末次忠司，海野仁，田中義人:氾濫シミュレーショ ンマニュアル(案),土木研究所資料,第 3400 号,pp.11-12,1996.

7) 東北地域災害科学研究会: 東北地域災害科学研究,pp.712,2001

8）土木学会水理委員会河川部会:2000年 9 月東海豪雨 災害に関するミニシンポジウム報告書, pp.13-51, 2001 